\title{
Interferon- $\gamma$ derived from cytotoxic lymphocytes directly enhances their motility and cytotoxicity
}

\author{
Purnima Bhat ${ }^{\star, 1,2}$, Graham Leggatt ${ }^{1}$, Nigel Waterhouse ${ }^{3}$ and lan H Frazer ${ }^{1}$
}

Interferon gamma (IFN $\gamma$ ) is a key moderator of cell-mediated immunity with diverse, mainly pro-inflammatory actions on immunocytes and target tissue. Recent studies have shown it may enhance anti-tumor and antiviral effects of CD8 T cells. Here we investigate the mechanisms by which IFN $\gamma$ mediates CD8 T-cell cytotoxic function. We show that in vivo, antigen-specific CD8 $T$ cells that produce INF $\gamma$ are necessary to effect rejection of skin grafts expressing OVA as a transgene in keratinocytes. The ability of CD8 T cells to produce IFN $\gamma$ enhanced their ability to migrate to the site of antigen-presenting skin cells. By in vivo imaging, we show that CTL motility, particularly speed, during graft rejection was enhanced by locally available IFN $\gamma$. We then used a reductionist two-cell model of CTL effectors and keratinocyte targets to investigate the effects of locally available (paracrine) and CTL-producing (autocrine) IFN $\gamma$ on the motility behavior and killing ability of the CTL. Using live-cell imaging by prolonged timelapse microscopy of primary effector CD8 T cells and antigen-expressing primary keratinocyte targets, we show that CD8 T-cell cytotoxic function and motility is enhanced by locally available IFN $\gamma$. Conversely, deprivation of either autocrine or paracrine IFN $\gamma$, or blockade of IFN $\gamma$ signaling to CTL markedly reduced their cytotoxic function, their kinematics, and effector cell survival. We conclude that in vitro and in vivo, autocrine production of IFN $\gamma$ by CTL enhances their motility and promotes killing of primary target keratinocytes. The absolute need for local IFN $\gamma$ to enable cytotoxic CD8 T-cell function is of significance for immunotherapy for chronic viral infection and for cancer.

Cell Death and Disease (2017) 8, e2836; doi:10.1038/cddis.2017.67; published online 1 June 2017

Cytotoxic CD8 T lymphocytes (CTL) are found in many solid tumors and provide an attractive target for immunotherapeutic manipulation. ${ }^{1,2}$ However, despite their presence, they appear to function sub-optimally in effecting target cell lysis. Inhibiting CTL regulatory mechanisms have shown promise as potential adjuvant cancer therapies. Vaccination together with TGF- $\beta$ blockade, ${ }^{3}$ IFN- $a$ therapy ${ }^{4}$ or inhibition of CTLA- $4,{ }^{5}$ or of PD-1/ PD-L1 interactions, ${ }^{6}$ have enhanced effector T-cell function in melanoma. Local cytokines such as IL-12 have been shown to promote intra-tumoural CD8 T-cell function. ${ }^{7,8} \mathrm{~A}$ favorable ratio of effector $\mathrm{T}$ cells to regulatory $\mathrm{T}$ cells is associated with a better prognosis, suggesting that CTL may play a role in controlling many malignancies. Human trials of immunotherapy in which there is marked activation of local effector T-cell function and inhibition of local regulatory $\mathrm{T}$ cells ${ }^{9}$ have shown benefit.

IFN $\gamma$ is released in large amounts by macrophages, activated CD8 T cells, natural killer T cells, and Th1 CD4 $\mathrm{T}$ cells. Its actions are varied, and tissue dependent; the IFN $\gamma$ receptor (IFN $\gamma \mathrm{R}$ ) heterodimer is widely expressed on immune and non-immune cells. ${ }^{10,11}$ Early in inflammation, it is a potent chemoattractant released by activated tissue macrophages, promoting recruitment of neutrophils, and $\mathrm{T}$ cells through paracrine signaling. It markedly increases T-cell-mediated killing by upregulating MHC-I expression on target cells, and may promote target cell differentiation and death directly. ${ }^{12,13}$ IFN $\gamma$ skews the helper T-cell response towards a Th1 profile, but may be inhibitory in some infection models by suppressing IL-17 and reducing neutrophil chemotaxis. ${ }^{14-16}$ Studies enhancing the expression of IFN $\gamma$ by CD8 T cells have shown improved anti-tumor responses in vivo in several mouse models. ${ }^{17,18}$

IFN $\gamma$ affects a variety of intracellular events in CD8 T cells via the IFN $\gamma$ R. It induces IL-12R expression ${ }^{19}$ and in murine models of infection, CTL proliferation and immunodominance appear to rely on IFN $\gamma .{ }^{20,21}$ IFN $\gamma$ may enhance the ability of CTL to kill via Fas/FasL in the absence of perforin. ${ }^{22}$ However, it may also directly increase T-cell apoptosis, and reduce proliferation. ${ }^{23}$ Thus reports on the actions of IFN $\gamma$ on CD8 T cells vary. In skin, IFN $\gamma$ appears to be essential to promoting T-cell migration to sites of inflammation, even in sterile conditions. $^{24,25}$ We have shown IFN $\gamma$ to be essential in mediating rejection of skin grafts expressing ovalbumin, ${ }^{26}$ but it is suppressive of CD8 T-cell function when other antigens are expressed. ${ }^{27}$

We have previously shown that the cytotoxic ability of CD8 T cells was associated with their kinematics in target tissue. ${ }^{28}$ Here we examine the mechanisms by which local IFN $\gamma$ affects CD8 T-cell motility and modulates the ability of CD8 effector $T$ cells to kill keratinocytes $(\mathrm{KC})$ expressing non-self antigen. In vivo, CTL needed to produce IFN $\gamma$ to achieve skin graft rejection and IFN $\gamma$ promoted $\mathrm{CTL}$ motility in tissue. In vitro, signaling by IFN $\gamma$ increased CD8 T-cell motility and speed, and markedly increased antigen-specific contact-mediated T-cell

\footnotetext{
${ }^{1}$ The University of Queensland Diamantina Institute, Translational Research Institute, 37 Kent Street, Woolloongabba, QLD 4102, Australia; ${ }^{2}$ Medical School, John Curtin School of Medical Research, Garran Rd, Australian National University, Canberra, ACT 2601, Australia and ${ }^{3}$ QIMR Berghofer Medical Research Institute, 300 Herston Road, Brisbane, 4006, QLD. Australia

${ }^{*}$ Corresponding author: P Bhat, The University of Queensland Diamantina Institute, Translational Research Institute, 37 Kent Street, Woolloongabba, QLD 4102, Australia; Tel: +61 400006 839; Fax: +612 612 52595; E-mail: purnima@ purnima.net

Received 04.11.16; revised 08.1.17; accepted 09.1.17; Edited by G Raschellà
} 
a

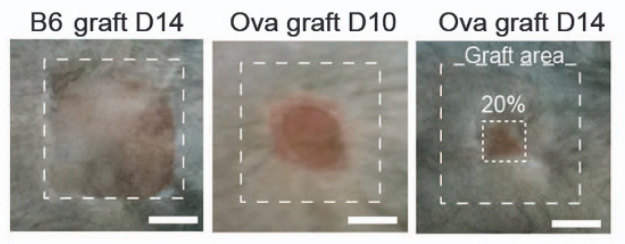

C
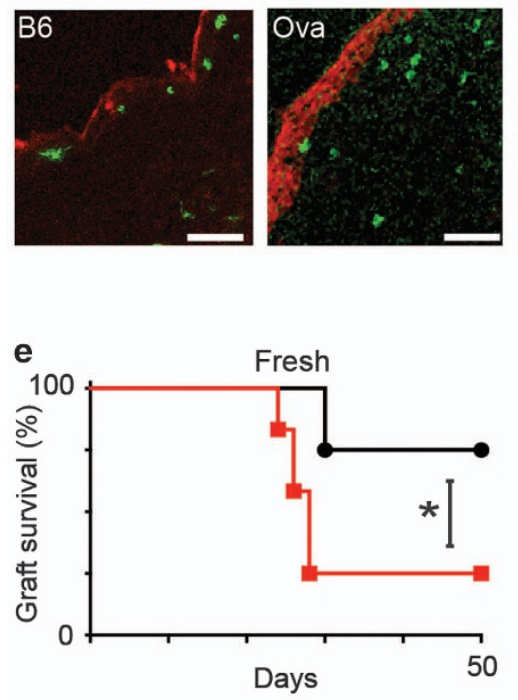

g
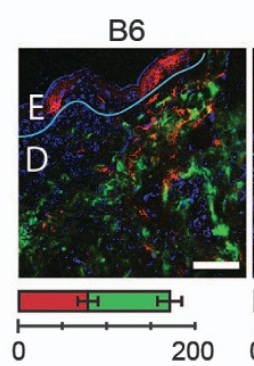

Imm-B6

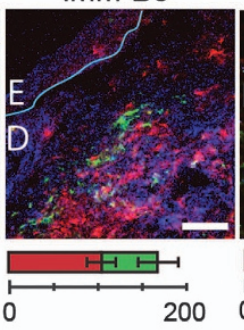

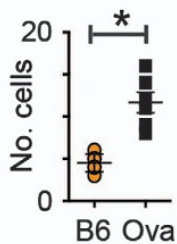

B6 Ova b

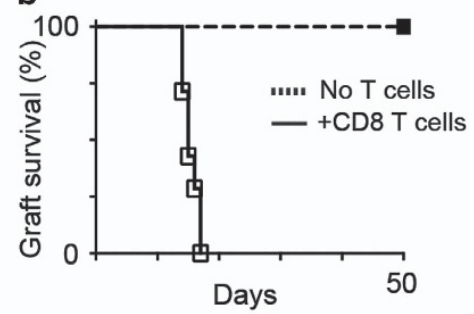

d

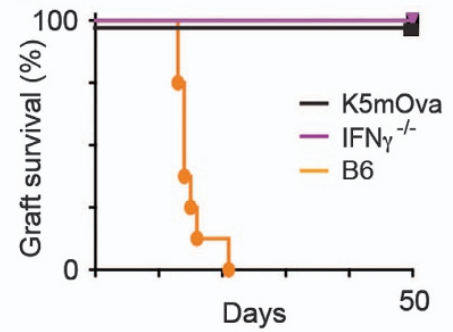

f
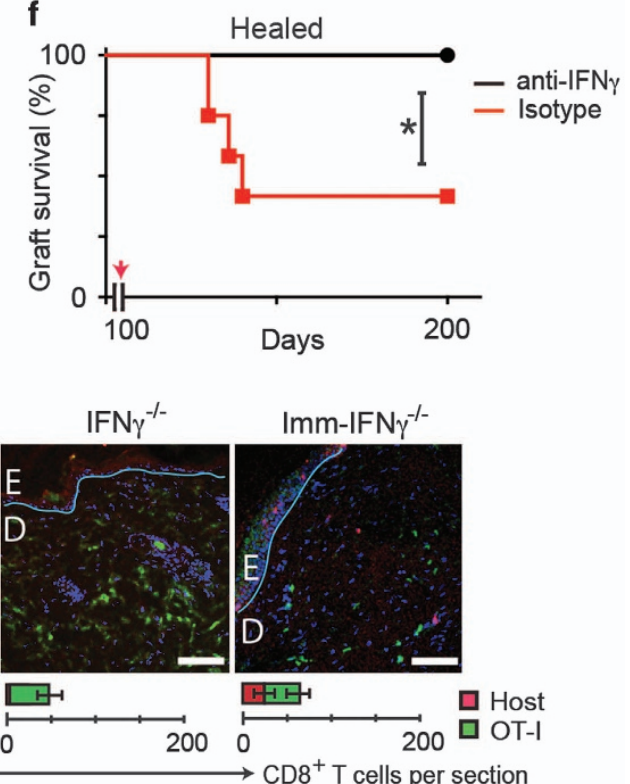

Figure 1 Interferon- $\gamma$ is required for skin graft rejection. Ear skin from B6 or K5mOVA donor mice was grafted on the flanks of B6 recipients. (a) $80 \%$ graft loss was denoted as rejection. (b) OVA skin grafted onto Rag1 ${ }^{-1-}$ mice with or without transferred $10^{6}$ naive CD8 T cells. (c) Section of OVA grafts onto B6 or OVA mice at day 10 stained for caspase-3 (red), CD8 (green; Bar, $100 \mu \mathrm{m}$ ); quantified per field of view. Data pooled from 2 experiments, error bars are SEM. (d) OVA transgenic grafts were placed on K5mOva, $\mathrm{IFN} \gamma^{-1-}$ or B6 recipients. Graph shows graft survival. (e) IFN $\gamma^{-1-}$ recipients received pre-primed CD8 cells by adoptive transfer, and were treated with anti-IFN $\gamma$ or isotype antibody $48 \mathrm{~h}$ prior to grafting of OVA skin, and weekly thereafter. Graph shows graft survival ( ${ }^{*} P<0.05$, Mantel-Cox test). (f) OVA skin grafts were placed on IFN $\gamma^{-1-}$ mice for 100 days. Recipients were then adoptively transferred with IFN $\gamma$-competent CTL, and anti-IFN $\gamma$ or isotype antibody as in (e). ${ }^{*} P<0.001$, Mantel-Cox test). (g) EGFP ${ }^{*}$ OT-1 CD8 T cells were adoptively transferred into OVA-naive B6 mice, OVA-immunized B6 mice, OVA-naive IFN $\gamma^{-1}$ - mice, or into OVA-immunized IFN $\gamma^{-1-}$ mice, before placing OVA skin grafts. Grafts were harvested after 10 days and stained for CD8. Confocal images were taken at graft edges and have been pseudocoloured to show native CD8 cells (red), transferred cells (green) and nuclei (blue). The basement membranes have been drawn in teal. (Bar, $100 \mu \mathrm{m}$ ). The average total cell numbers of T cells in each field from duplicate fields of two samples from a typical experiment is indicated in the graphs below. Error bars are S.D.

killing. We show IFN $\gamma$ enhances the cytolytic ability and the kinematics of CTL both by paracrine and autocrine mechanisms of signaling.

\section{Results}

IFN $\gamma$-producing CD8 $\mathrm{T}$ cells are required for graft rejection. Rejection of antigen-expressing skin grafts is a model of CTL-dependent immunopathology. To examine the role of IFN $\gamma$ in effector function of $\mathrm{T}$ cells against epithelial cells in vivo, we grafted skin expressing OVA onto B6 mice. These grafts are rejected at around 14 days (Figures 1a and $b$ ). At this time, the grafts can be seen to contain large numbers of infiltrating CD8 T cells, and extensive expression of caspases in keratinocytes (Figure 1c). By contrast, nonrejecting isografts showed minimal cellular infiltration and 

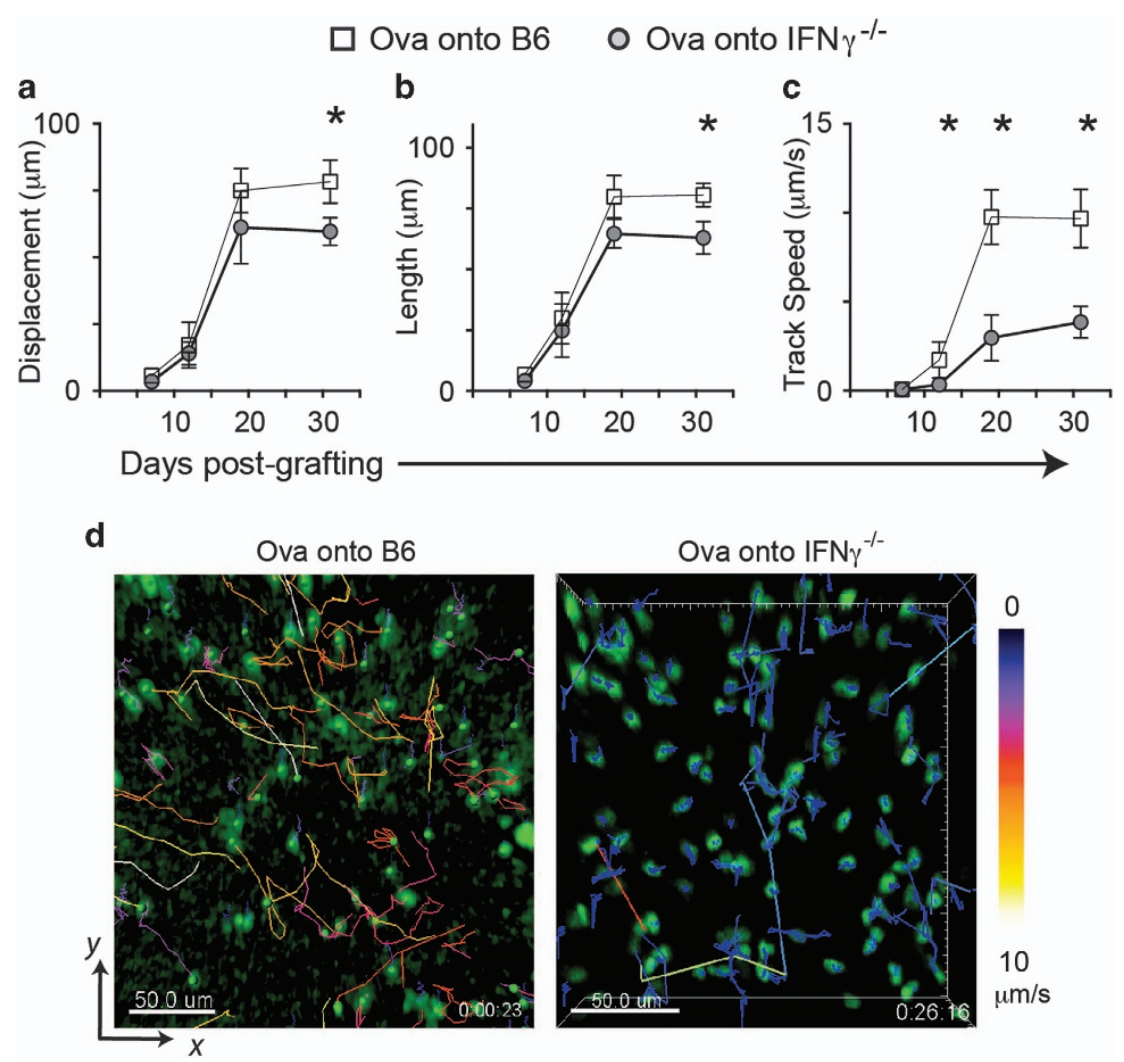

Figure 2 Motility of CTL in tissues is enhanced by IFN $\gamma$. EGFP+CTL were adoptively transferred into B6 or IFN $\gamma^{-1-}$ mice before OVA skin was grafted. Post grafting, mice were anaesthetized and the graft edges imaged by 2-photon microscopy. Multiple sites per graft were imaged for 20-30 min each. EGFP+ cells were identified and tracked by software, and analyzed for CTL displacement (a), length of travel (b) and speed of travel (c) during the imaged time. Data are pooled from 4 regions imaged per graft, from 3 mice per time point. Averages are shown, error bars are SD. ( $\left.{ }^{*} P<0.05\right)$ (d) Representative images of grafts on B6 recipients and IFN $\gamma^{-1-}$ recipients at day 19 post graft placement. CTL have been identified and tracked with track color coding for average speed of cell movement over the period of imaging. Bar, $50 \mu \mathrm{m}$ (see also Supplementary Movies S1 and 2)

minimal expression of activated caspases, confirming that infiltrating antigen-specific CD8 $T$ cells play a role in mediating the caspase-dependent death of keratinocytes that leads to graft failure.

OVA skin grafts placed on IFNY ${ }^{-1-}$ recipient mice were not rejected (Figure 1d). This might reflect failure of T-cell activation, as IFN $\gamma$ facilitates in vivo priming of naive $\mathrm{T}$ cells, or a requirement for IFN $\gamma$ to enable T-cell function. We transferred $10^{6}$ OVA-primed $\mathrm{CD} 8^{+} \mathrm{CD} 44^{\text {high }} \mathrm{CD} 8 \mathrm{~T}$ cells to IFN $\gamma^{-1-}$ mice bearing OVA skin grafts, either placed at the time of T-cell transfer or healed-in for 100 days. Recent OVA grafts were promptly rejected in animals with transferred primed T cells, but not in animals comprising only cells naive to OVA (Figures 1e and f) suggesting IFN $\gamma$-deficiency compromises T-cell activation. Healed-in OVA grafts showed inflammation and graft shrinkage after transfer of primed T cells, with 7 of 12 rejected (Figure 1f). Administration of anti-IFNY antibody negated the effects of the transferred cells.

We tested whether IFN $\gamma$ was required to recruit pre-primed $\mathrm{T}$ cells to effect rejection. We transferred $10^{6} \mathrm{EGFP}^{+} \mathrm{CD} 8^{+}$ CD44 ${ }^{\text {high }}$ OT-1 effector T cells from mice primed by immunization with OVA into OVA-naive mice that were either IFNYcompetent or $\mathrm{IFN}^{-/-}$, thus providing in each animal a primed and an unprimed population of T cells. Also, these effector $T$ cells were transferred into mice that had been immunized with OVA thus providing two primed populations of T cells: host and transferred. These mice recipient of $T$ cells were then grafted with OVA skin. Grafts on unimmunized IFNY ${ }^{-1-}$ animals recruited fewer cells than grafts on immunized IFN $\gamma$ competent animals. Immunization of IFN $\gamma^{-1-}$ mice with OVA was effective in facilitating recruitment of host cells to OVA grafts (Figure 1g). These data confirm that host IFN $\gamma$ facilitates effective trafficking of antigen-specific CD8 $T$ cells and may contribute to CTL activation.

T-cell motility in tissue increases with rejection. We have previously observed altered CD8 T-cell kinematics associated with acquisition of CD8 T-cell effector functions in vitro. ${ }^{28} \mathrm{We}$ observed in vivo the motility of CTL in OVA grafts placed on IFN $\gamma$-deficient and IFN $\mathrm{N}_{\gamma}$-competent mice. OVA grafts were placed on $\mathrm{B} 6$ or $\mathrm{IFN}^{-1-}$ mice recipient of $\mathrm{EGFP}^{+} \mathrm{CD}^{+}$ CD44 high OT-1 effector T cells. Grafts were examined by intravital imaging from day 7 , after bandage removal. Early post-grafting, CTL in both $\mathrm{B} 6$ and $\mathrm{IFN}^{-1-}$ recipients displayed similar characteristics of immobility and arrest. By 12 days, when signs of graft rejection were visible, some CTL were active, showing increase in track displacement and length similarly in both $\mathrm{B} 6$ and IFNy ${ }^{-1-}$ mice, but reduced speed in the absence of IFN $\gamma(P=0.02$; Figures 2a-c). OVA grafts on all B6 mice had completely rejected by 14 days. By 
day 19, there were marked differences between the kinematics of $\mathrm{CTL}$ in IFN $\gamma$-competent mice compared with their IFN $\gamma$-deficient counterparts, with the latter showing less speed $(P=0.01)$, and trending to greater displacement $(P=0.06)$ and track length $(P=0.07$; Figures 2c and $\mathrm{d})$. These effects were even greater at 31 days after healing was complete (displacement $P=0.02$; length $P=0.01$; speed $P=0.002)$. These data suggest that in the absence of acute inflammation, and after loss of antigen, locally available IFN $\gamma$ enhanced kinematics of CTL in vivo.

IFN $\boldsymbol{\gamma}$ enhances target killing. Death of $\mathrm{KC}$ targets in vivo is slow and not readily amenable to direct intravital imaging. ${ }^{28,29}$ We have previously used prolonged time-lapse imaging of primary target and effector cells in vitro to show that the mechanism of killing was associated with T-cell kinematics. ${ }^{28}$ We utilized this method to determine the role of IFN $\gamma$ in CTL cytotoxicity to keratinocytes. We isolated EGFP ${ }^{+} \mathrm{CD} 8 \mathrm{~T}$ cells from mice primed to OVA in vivo, and from naive mice. As expected, IFN $\gamma$ expression was high in primed cells from IFN $\gamma$-competent mice, when compared with naive cells, and undetectable in primed cells from $\mathrm{IFN}^{-1-}$ mice. However, CD44, a marker of T-cell activation, was elevated in primed cells from both IFN ${ }^{-}$-competent and $\mathrm{IFNy}^{-1-}$ mice (Figures $3 a$ and b). Primed cells were co-cultured with primary keratinocytes loaded with OVA and imaged for $30 \mathrm{~h}$ (Supplementary Movie S3). OVA-primed CD8 T cells from both OT-1 and B6 mice killed KC with statistically similar efficiencies (Figure 3c). However, IFN $\gamma^{-/-}$CD8 T cells killed markedly less efficiently than IFN $\gamma$-competent cells $(P<0.005$ $\mathrm{B} 6$ versus IFN $\gamma^{-1-}$; Figure 3c). The addition of anti-IFN $\gamma$ to a co-culture of IFN $\gamma$-competent CTL and antigen-loaded $\mathrm{KC}$ resulted in markedly reduced target cell killing (Figure $3 \mathrm{~d}$ ). These data suggest that killing of KC by CTL was enhanced in the presence of IFN $\gamma$. If $\mathrm{KC}$ from IFN $\mathrm{R}^{-1-}$ mice were used as targets, killing by primed IFN $\gamma$-competent $\mathrm{CTL}$ was overall less efficient (Figure 3e), but was further inhibited by antiIFN $\gamma$ antibody (Figure 3e). This suggests that both IFN $\gamma$ mediated $\mathrm{KC}$ killing, and non IFN $\gamma$-mediated killing by CTL were affected by locally supplied IFN $\gamma$.

In vivo, IFN $\gamma$ is supplied by many cells and is thus available via paracrine signaling to infiltrating CD8 T cells. To determine further the effect of locally available IFN $\gamma$ on CTL killing, recombinant IFN $\gamma$ (rIFN $\gamma$ ) was added to co-cultures of antigenloaded KC targets and CTL. We first confirmed that at the concentrations of $\mathrm{rIFN} \gamma$ that we used $(0.1 \mathrm{ng} / \mathrm{ml})$, there was no increased death of $\mathrm{KC}$ above baseline in the absence of CTL in the co-culture (Supplementary Figure 1). Addition of rIFN $\gamma$ to effector-target cultures with IFN $\gamma$-competent CTL resulted in a small but significant increase in cytolytic function - which was abrogated by the addition of anti-IFN $\gamma$ (Figures $3 f$ and $\mathrm{g}$ ). Addition of rIFN $\gamma$ to co-cultures of $\mathrm{KC}$ and IFN $\gamma^{-1-} \mathrm{CTL}$ also augmented killing of $\mathrm{KC}$ by $\mathrm{IFN} \gamma^{-1-} \mathrm{CTL}$ (Figure 3h), suggesting that paracrine IFN $\gamma$ affected activated CD8 $T$ cells, independent of whether they produced the cytokine themselves. The levels of killing did not reach that of IFNycompetent CTL (Figure 3c), however, suggesting that, although IFN $\gamma^{-1-} \mathrm{T}$ cells are competent at cytolysis when supplied with IFN $\gamma$ (Figure 3h; $P=0.032$ rIFN $\gamma$ versus $\mathrm{PBS}$ ), the production and autocrine signaling of IFN $\gamma$ may be important to T-cell cytolytic function.

IFN $\gamma$ directly promotes CTL cytotoxicity. IFN $\gamma$ up-regulates antigen presentation on epithelial cells. To determine whether in our model IFN $\gamma$ was acting directly on CTL or on targets, we pre-treated CTL with IFN $\gamma$. OVA-primed CTL were treated for $4 \mathrm{~h}$ with $\mathrm{rIFN} \gamma$, and then co-cultured with $\mathrm{KC}$ and imaged for $30 \mathrm{~h}$. CTL pre-stimulated with rIFN $\gamma$ killed targets significantly better than untreated T cells (Figures $4 \mathrm{a}$ and c) even when targets did not express the IFN $\gamma$-receptor (Figure 4b). CTL lysis of KC is thus enhanced by IFN $\gamma$, even when the $\mathrm{KC}$ cannot respond to secreted IFN $\gamma$. We then investigated whether IFN $\gamma$ production by effector $\mathrm{T}$ cells enhanced their own effector function. We pre-incubated IFN $\mathrm{N}_{\gamma}$ competent primed CTL with anti-IFN $\gamma$ antibody, which is not cell permeable, for $4 \mathrm{~h}$, washing cells thoroughly before coculture with $\mathrm{KC}$ target cells. Killing of target $\mathrm{KC}$ was significantly inhibited, but not abrogated, by anti-IFN $\gamma$ pretreatment of CTL (Figures $4 \mathrm{a}$ and $\mathrm{c}$ ). There was no recovery in levels of cytotoxicity over $30 \mathrm{~h}$. We co-cultured antibodytreated CTL with IFN $\gamma \mathrm{R}^{-1-} \mathrm{KC}$ to assess the effect of IFN $\gamma$ inhibition on non-IFN $\gamma$-mediated cytotoxicity. In this case, cytotoxicity was almost completely abrogated, suggesting that CTL may be reliant on IFN $\gamma$ at a metabolic level to effect any killing, even non-IFN $\gamma$ cytokine mediated killing.

IFN $\boldsymbol{\gamma}$ promotes CD8 T-cell motility. Time-lapse movies of target-effector cell co-cultures were analyzed for CTL displacement, track length and mean track speed (Figure 5a and Supplementary Movie S2) The net patrol area of CTL increased with rIFN $\gamma$ treatment, and was reduced with inhibition of IFN $\gamma$ (Figure 5b). The addition of rIFN $\gamma$ to the co-cultures markedly increased CTL vector displacement (rIFN $\gamma$ mean $95 \mu \mathrm{m}$; untreated mean $55 \mu \mathrm{m} ; P=0.043, \mathrm{~K}-\mathrm{S}$ test) and distance traveled (rIFN $\gamma$ mean $254 \mu \mathrm{m}$; untreated mean $218 \mu \mathrm{m} ; P=0.023, \mathrm{~K}-\mathrm{S}$ test; Figures $5 \mathrm{c}$ and $\mathrm{d}$ ). CTL treated with IFN $\gamma$ traveled with average speeds of $0.41 \mu \mathrm{m} / \mathrm{s}$, significantly faster than untreated cells (average $0.33 \mu \mathrm{m} / \mathrm{s}$; $P=0.044, \mathrm{~K}-\mathrm{S}$ test; Figure $5 \mathrm{e}$ ). The addition of anti-IFN $\gamma$, but not isotype antibody, inhibited the stimulatory effects of rIFN $\gamma$.

To establish whether the increased motility was due to the effects of IFN $\gamma$ on effector cells or on KC, CTL were pre-treated with anti-IFN $\gamma$, or with rIFN $\gamma$ for four hours prior to co-culturing with targets, as above (Figure $6 \mathrm{a}$ ). Treatment of $\mathrm{T}$ cells with rIFN $\gamma$ markedly increased their vector displacement (mean $137 \mu \mathrm{m}, P<0.05 \mathrm{cf}$. untreated; Figure $6 \mathrm{~b})$ and distance traveled (mean $218 \mu \mathrm{m}, P<0.05 \mathrm{cf}$. untreated; Figure $6 \mathrm{c}$ ). Likewise, cells moved faster with IFN $\gamma$ pre-treatment (Figure $6 \mathrm{~d}$ ), with average speeds of $0.52 \mu \mathrm{m} \mathrm{s}^{-1}$ (mean $P<0.05$ cf. untreated). IFN $\gamma$ thus directly promotes CD8 T-cell motility. Pre-treatment of CD8 T cells with anti-IFN $\gamma$ for four hours may be predicted to have little effect on CD8 T-cell kinematics as the cells would produce IFN $\gamma$ in response to antigen presentation by $\mathrm{KC}$. We found $4 \mathrm{~h}$ of pre-treatment with anti-IFN $\gamma$ inhibited CTL motility: displacement, track length and mean speed were significantly reduced, while treatment with an isotype control antibody for the same amount of time had no effect. (Figures $6 b-d$ ). 
a
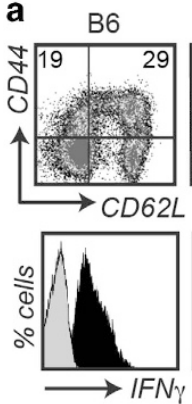

C

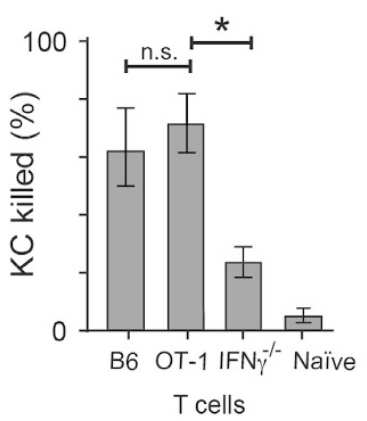

f

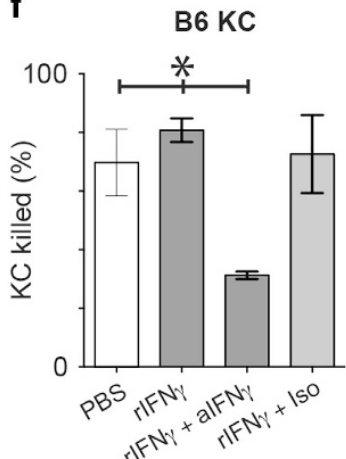

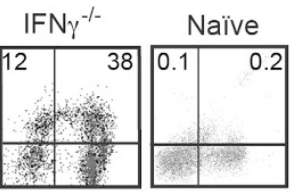

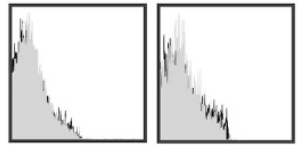

d

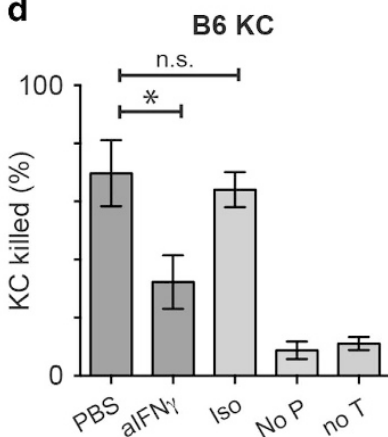

g $\quad \mathrm{IFN} \gamma \mathrm{R}^{-1 /} \mathrm{KC}$

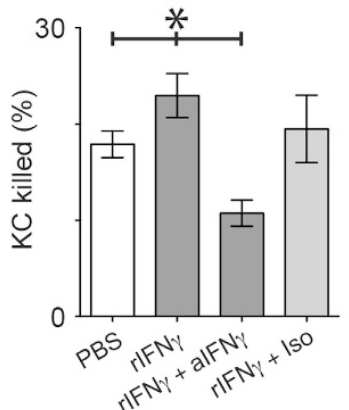

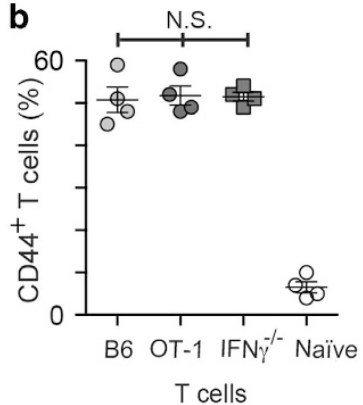

e

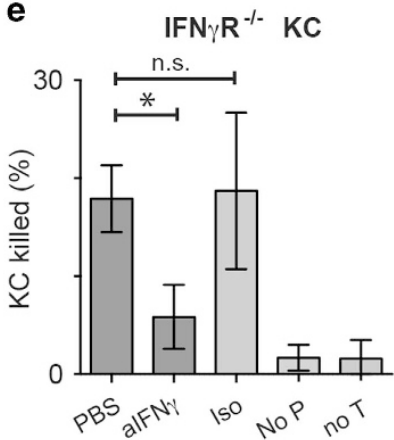

h

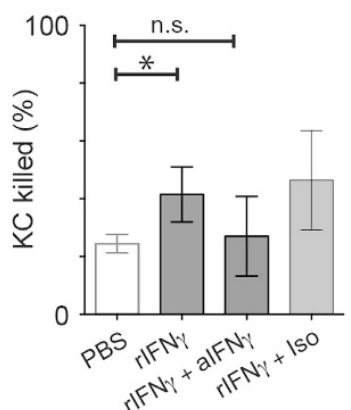

Figure 3 Exogenous IFN $\gamma$ promotes $\mathrm{KC}$ killing by T cells via IFN $\gamma$ receptor on target cells. (a) Flow cytometry analysis of splenic T cells gated by size, CD8 expression, and EGFP expression, from OVA-immunized OT-I, B6, IFN $\gamma^{-1-}$, or OVA-naive B6 mice (black, anti-IFN $\gamma$; gray, isotype antibody). $N=4$. (N.S., not significant between groups, ANOVA.) (b) Percentage of total CD8 T cells from (a) that express CD44. $N=4$, error bars are SD. (c-h) These cells were co-cultured with SIINFEKL-loaded target keratinocytes derived from B6 (IFN $\gamma \mathrm{R}^{+/+}$) or IFN $\gamma \mathrm{R}^{-1-}$ mice in the presence of indicator dye for intracellular activated caspases, and imaged by time-lapse fluorescence microscopy. Target cell death was determined by analyzing movies using software to identify spots based on size $(>12 \mu \mathrm{m})$ and red fluorescence, and expressed as a percentage of the total number of $\mathrm{KC}$ at $30 \mathrm{~h}$. Duplicate wells were averaged, $N=4$. Error bars are standard deviations. ( ${ }^{*} P<0.05$, 'NS', not significant, Mann-Whitney test; ${ }^{*} P<0.05$, 'n.s.', not significant, ANOVA) (d) OT-I CTL were co-cultured with IFN $\gamma \mathrm{R}^{+/+}$or IFN $\gamma \mathrm{R}^{-/-}$(e) KC. Co-cultures were treated with anti-IFN $\gamma$ or PBS. Included in each experiment were control wells: with isotype antibody (Iso), without peptide (No P), and without T cells (No T). (f) OT-I CTL were co-cultured with IFN $\gamma \mathrm{R}^{+/+}$or IFN $\gamma \mathrm{R}^{-1-}$ (g) $\mathrm{KC}$ and were treated with rIFN $\gamma$, or rIFN $\gamma$ and anti-IFN $\gamma$, or rIFN $\gamma$ and isotype antibody. (h) IFN $\gamma^{-1-}$ CD8 T cells were co-cultured with SIINFEKL-loaded B6 KC. Cultures were treated with rIFN $\gamma$, or rIFN $\gamma$ and anti-IFN $\gamma$, or rIFN $\gamma$ and isotype antibody

We investigated whether IFN $\gamma$ had an effect on T-cell survival, which in monoculture is $>85 \%$ at $30 \mathrm{~h}$ (not shown). We showed previously that CTL loss accompanied target cell loss, usually after prolonged periods of attachment. ${ }^{28}$ Neither pre-incubation with rIFN $\gamma$, nor addition of rIFN $\mathrm{N}_{\gamma}$ to the coculture, altered the rate of apoptosis of CTL. Pre-incubation with anti-IFN $\gamma$, however, resulted in a significant $(P<0.05 \mathrm{cf}$. untreated and isotype) reduction of CD8 T-cell survival over $30 \mathrm{~h}$ (Figure 6f). CTL-derived IFN $\gamma$ seems to contribute to T-cell survival of IFN $\mathrm{N}_{\gamma}$-producing cells by autocrine signaling.

We next investigated these effects on IFN $\gamma$-deficient T cells. IFN $\gamma^{-1-}$ in vivo OVA-primed T cells from IFNy ${ }^{-1-}$ mice were pre-incubated with $\mathrm{rIFN} \gamma$, or alFN $\mathrm{N}_{\gamma}$ for $4 \mathrm{~h}$ prior to co-culturing with target KC expressing SIINFEKL peptide. Without treatment, IFN $\gamma^{-1-}$ T cells displayed reduced vectorial displacement $(89.8 \mu \mathrm{m}$ versus $56.0 \mu \mathrm{m}, P<0.05)$ and total travel distances $(85.7 \mu \mathrm{m}$ versus $57.8 \mu \mathrm{m}, P<0.05)$ compared with IFN $\gamma$-competent CTL (Figure $7 \mathrm{a}$ and $\mathrm{b}$ ). Their track speed was also slower ( 0.36 versus $0.64 \mu \mathrm{m} / \mathrm{s}, P<0.05$; Figure $7 \mathrm{c}$ ). Incubating IFN $\gamma$-deficient cells with rIFN $\gamma$ markedly enhanced CTL kinematics, bringing them up to levels comparable to IFN $\gamma$-competent cells similarly treated with rIFN $\mathrm{N}_{\gamma}$ indicating these cells responded similarly to locally supplied IFNY. Incubation with alFN $\gamma$ had no effect on the behavior of 
a
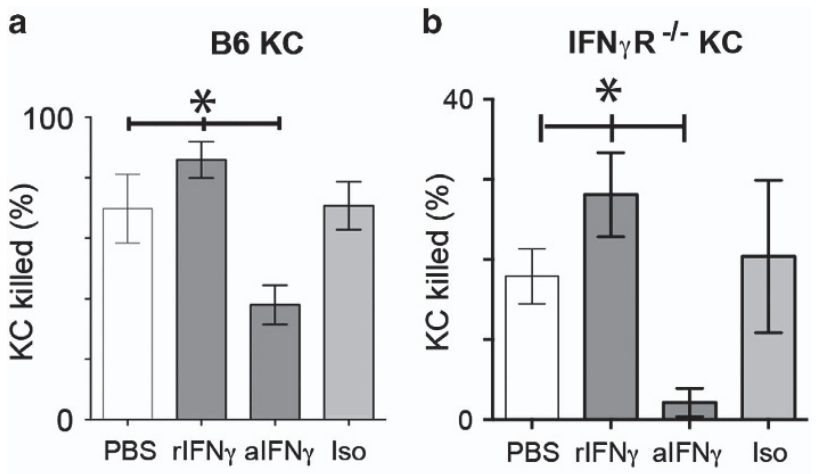

C

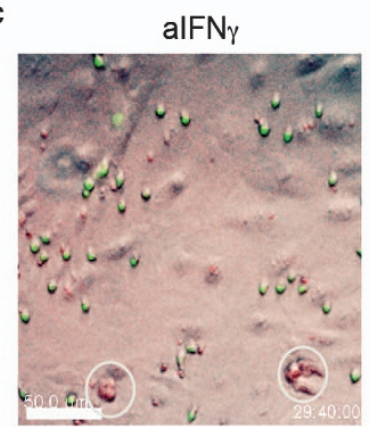

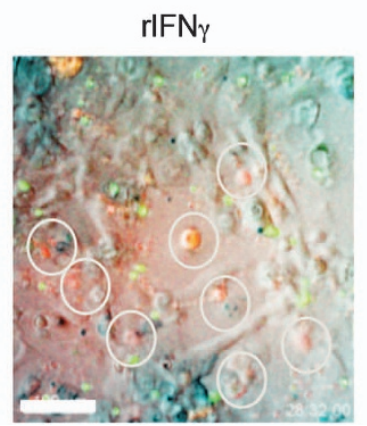

Figure 4 Modulation of IFN $\gamma$ signaling in CTL affects cytotoxic function. EGFP+OT-1 CTL were incubated with PBS, rIFN $\gamma$, anti-IFN $\gamma$ or isotype antibody for $4 \mathrm{~h}$, then washed thoroughly and added to SIINFEKL-loaded (a) B6 or (b) IFN $\gamma \mathrm{R}^{-1-}$ $\mathrm{KC}$ along with indicator dye for activated caspase. Co-cultures proceeded for $30 \mathrm{~h}$, and were imaged by fluorescence time-lapse microscopy. Keratinocyte death was determined as in Figure 3. $\left({ }^{*} P<0.05\right.$, 'NS', not significant, ANOVA). (c) Frames of representative fields of co-cultures after $28 \mathrm{~h}$ of imaging. Merged red, green and brightfield images shown. Dead KC fluoresce red. EGFP+ ${ }^{+}$CTL are green. Dead KC are shown by white rings. Scale bar is $50 \mu \mathrm{m}$

IFN $\gamma$-deficient cells. While inhibiting IFN $\mathrm{N}_{\gamma}$ in IFN $\gamma$-sufficient cells reduced T-cell survival, untreated and antibody-treated IFN $\gamma$-deficient cells displayed minimal loss. Conversely, Treatment with rIFN increased CTL mortality, reflecting activation-induced cell death associated with increased killing ability (Figure $7 \mathrm{~d}$ and $3 \mathrm{~h}$ ).

\section{Discussion}

In vivo and in vitro, CTL kill target cells after a period of prolonged contact and at a low rate. ${ }^{28,30}$ Using a reductionist two-cell system, we now describe CTL-mediated killing of targets that is reliant on IFN $\mathrm{N}_{Y}$ at multiple interfaces including recruitment, motility, killing and survival.

IFN $\gamma$-deficient animals were unable to reject skin grafts expressing ovalbumin, despite a full complement of T cells (Figure 1b). Although some studies have suggested that in an IFN $\gamma$-deficient environment, priming is suboptimal, ${ }^{31-33}$ the presence of host cells in graft tissue after immunization suggested priming was occurring. It was more likely therefore that IFN $\gamma$ was necessary for CTL cytotoxic function. CD8 T cells without IFN $\gamma$ R2 can't effect cytolysis in a chromium release assay, although they express Fas, perforin and $\mathrm{IFN} \gamma \cdot{ }^{34}$

IFN $\gamma$ is a potent chemoattractant for CD8 T cells in inflamed tissue, amplifying antiviral responses. ${ }^{35}$ However, in skin, IFN $\gamma$

has been reported as redundant for CTL recruitment or efficacy of function. ${ }^{36}$ We found transferred pre-primed IFN $\gamma$-competent CD8 $T$ cells sufficient to reject fresh grafts and consistent with previous work showing the resistance of grafts to rejection without local inflammatory stimuli CTL also partially rejected well-healed grafts. ${ }^{37}$ Since inhibition of IFNY increased CTL death ex vivo, it may also reflect a shorter lifespan of transferred cells in an IFN $\gamma$-deficient environment. We note that the lack of IFN $\gamma$ expression in tissues resulted in fewer CD8 T cells migrating to the inflammatory site (Figure 1e), however they were sufficient to effect rejection. These effects may be due to in vivo reduction in antigenexpression by $\mathrm{KC}$ in an IFN $\gamma$-deficient environment, although the restoration of graft rejection by transfer of IFN $\gamma$-competent CTL suggests antigen presentation was sufficient.

IFN $\gamma$ has many tissue-specific effects in inflammation including enhancing CD8 T-cell migration and priming in tissue by antigen-presenting cells, upregulating MHC-I expression on targets, all of which enhance CD8 T-cellmediated target cell apoptosis in inflammation. However, rather than enhancing T-cell motility, inflammation appears to lead to arrest of CD8 T cells early in the rejecting skin graft, noted by us and others. ${ }^{29}$ Late in the process, when there is less tissue edema and inflammation, CTL are highly motile; less so in an IFN $\gamma$-deficient environment (Figure 3). We speculate that early in graft rejection, local factors such as hypoxia and edema may contribute to limiting motility of IFNycompetent CTL, which are inherently highly motile, and whose kinematics are further enhanced by circulating IFN $\gamma$. Previous studies have shown the presence of antigen slows CTL, with increase in T-cell motility when antigen levels were reduced. ${ }^{38}$ Rejected graft sites no longer have antigen, and thus the activity of the local CTL in the region reflects their motility in the absence of antigen, while within intact grafts, antigen is slowing down the CTL. Nevertheless, IFNY ${ }^{-1-}$ recipients do not reject OVA grafts, implying a deficiency in T-cell function, which may also be reflected in their motility.

The enhanced kinematics of CTL in response to IFNy resulted in the cells covering a larger migratory region, both in vector distance, and by track length taken, both in vivo and in vitro (Figures 2 and 5). These aspects of enhanced motility suggest an increased likelihood of target cell being encountered. It was speed which most closely correlated with function, particularly illustrated by treatment with anti-IFN (Figure 5e). It is not clear whether inhibition of autocrine IFNY lead to metabolic disturbances resulting in both cell slowing and impairment of killing, or whether the slowing down of the cells merely inhibited their ability to seek and kill targets. As T cells were incubated with a large excess of targets in our co-culture systems, we speculate the former is more likely.

Although $\mathrm{KC}$ are sensitive to non-contact dependent IFN $\gamma_{-}$ mediated killing, the production of IFN $\gamma$ by effector cells did not appear to be sufficient to kill bystander cells here, as evidenced by lack of KC death in co-cultures without peptide-loading (Figures $3 d$ and e). Secretion of IFN $N_{Y}$ by antigen-specific CD8 $T$ cells in a similar co-culture system demonstrated activation of IFN $\gamma$-dependent STAT1 in bystander cells but formation of an immunological synapse was crucial to the release of IFN $\gamma$, indicating antigen-specificity of IFN $\gamma$ release. ${ }^{39}$ This finding is consistent with our data that 

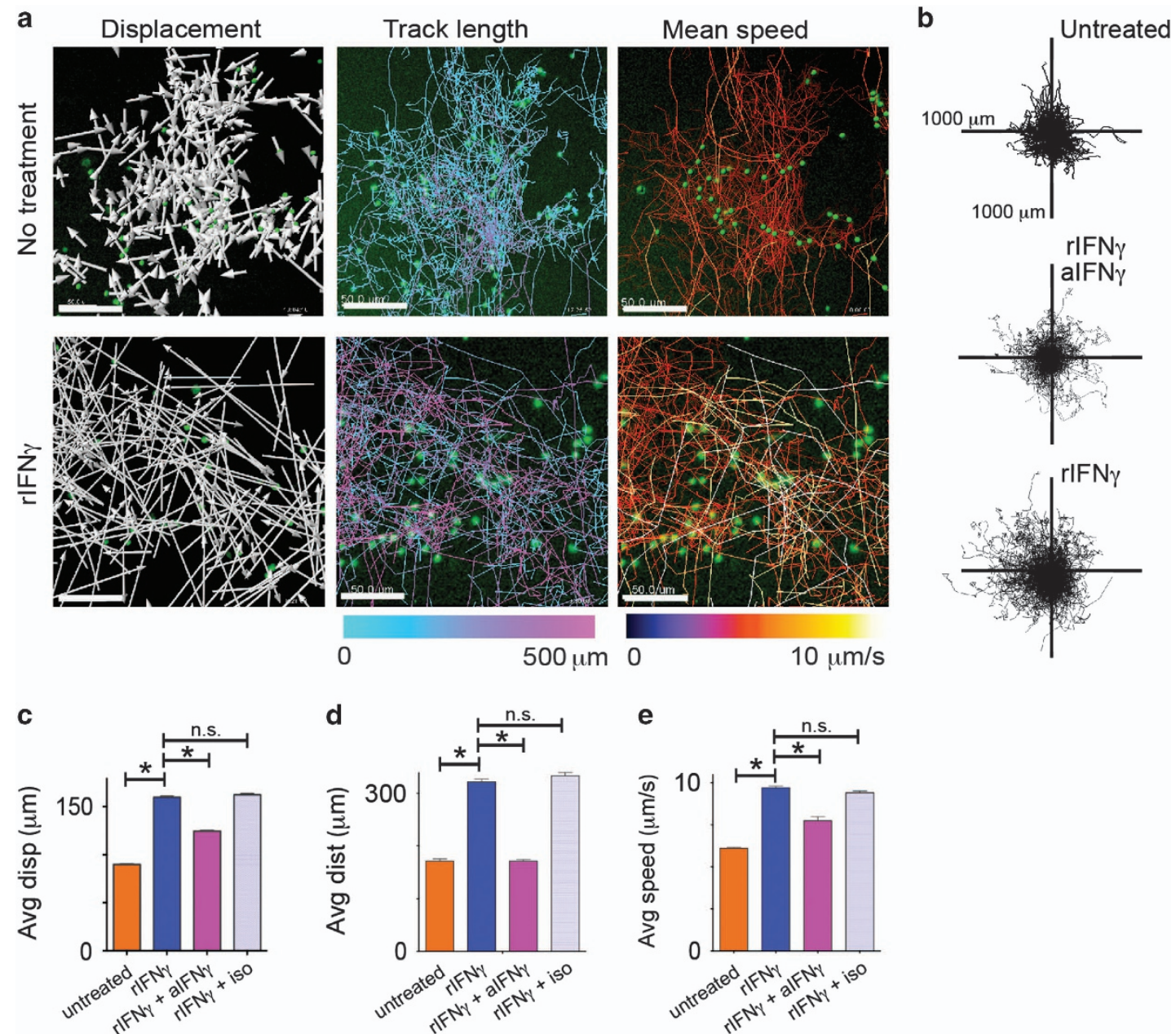

Figure 5 Exogenous IFN $\gamma$ promotes CD8 T-cell motility and enhances cytotoxicity. (a) Co-cultures of EGFP+OT-I CTL and SIINFEKL-loaded or untreated KC were imaged for $30 \mathrm{~h}$ by fluorescence time-lapse microscopy. Recombinant IFN $\gamma$ was added at time 0 . Representative images of tracks created by CTL as they traveled among KC targets have been mapped by software. Vector displacement of the tracks is shown by white arrows. Length of the traveled tracks and mean speed of travel is indicated by the colored legend bars (scale bars, $50 \mu \mathrm{m}$ ). (b) Translated travel tracks from (a) have been plotted from origin showing the distance and spread of the path traveled by the cells within the field of view. Each plot shows the result for one typical experiment of three independent experiments. (c-e) Displacement (c), distance traveled (d) and speed (e) of CD8 T cells in co-culture with antigen-loaded target KC. Average values of four movies are shown ( $>400$ cells). Error bars are S.E.M. $\left({ }^{\star} P<0.05\right.$, n.s. not significant)

activated CD8 $\mathrm{T}$ cells do not kill KC unless they express cognate antigen, and that $\mathrm{KC}$ deficient in IFN $\gamma$ receptor are more resistant to cell-mediated cytolysis. We observed almost no apoptosis of KC, as evidenced by caspase activation, without direct contact of KC with effector cells, although there may have been non-cytolytic STAT1 activation in surrounding cells not detectable in our assay. Additionally, IFN $\gamma$ has been shown to stimulate production of pro-inflammatory cytokines such IL-33 - a member of the IL-1 family - in keratinocytes. ${ }^{40}$ IL-1 directly enhances the activation of antigen-specific OT-1 CD8 T cells in vivo as evidenced by migration into peripheral tissues and in vivo cytotoxicity assays. ${ }^{41}$ This suggests that target keratinocytes may have the ability to directly enhance CD8 T-cell cytotoxicity in an inflammatory environment, and may be the mechanism by which CD8 T-cell kinematics and cytotoxic function are enhanced in our model.

Pre-incubation of CD8 T cells with IFN $\gamma$ directly enhanced CD8 T-cell cytolysis independent of its effects on target cells. CD8 $\mathrm{T}$ cells not expressing the IFN $\gamma \mathrm{R}$ are not able to lyse antigen-expressing cells, indicating the cytolytic function of these cells is dependent upon their IFN $\gamma \mathrm{R} .{ }^{34}$ By providing an environment rich in IFN $\gamma$, CD4 T helper 1 cells and natural killer $\mathrm{T}$ cells can also potentially enhance CTL cytolytic function in inflammation. By corollary, production of downregulators of IFN $\gamma$ may directly reduce CD8 cytolysis, a pathway by which tissues may protect themselves from inflammatory damage. ${ }^{42}$ IFN $\gamma$ stimulates the production of other cytokines from cells in an inflamed environment including IL-1 by innate immunocytes, which has been shown to markedly enhance the antiviral function of CD8 T cells. ${ }^{41} \mathrm{We}$ speculate that this may be another mechanism by which IFN $\gamma$ released into the local environment works to enhance function of CTL themselves. CD8 effector cells in tissue vary in their sensitivity to IFN $\gamma$, likely reflecting different populations, not all of which are equally cytolytic, ${ }^{43}$ suggesting a potential target for immune modulation.

IFN $\gamma$ has been purported to play a key role in antigeninduced T-cell death. ${ }^{44}$ The modest but significant increase in 


\section{a}
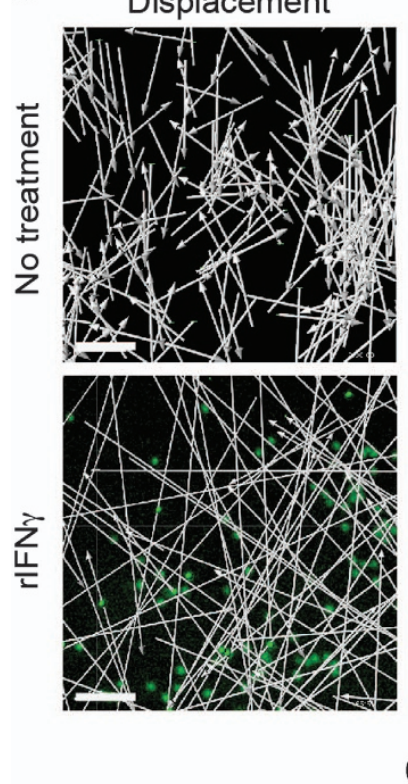

b

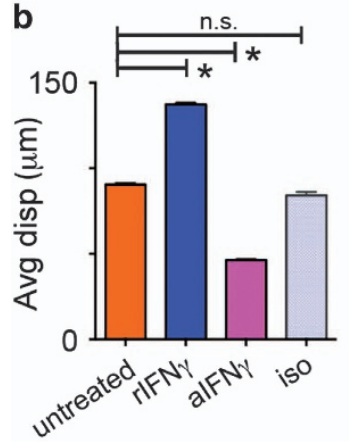

Track length
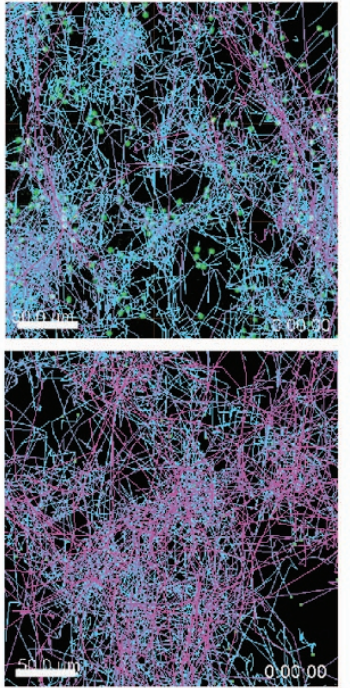

0

c

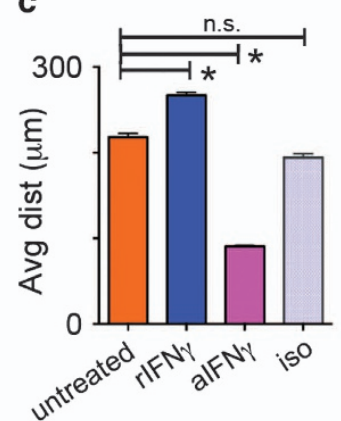

Mean speed
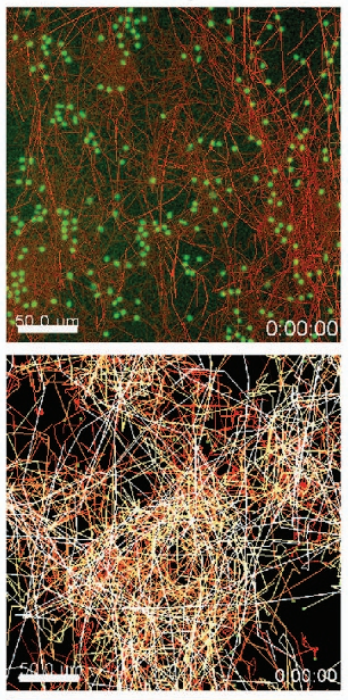

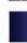

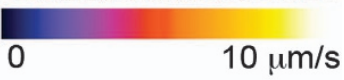

d

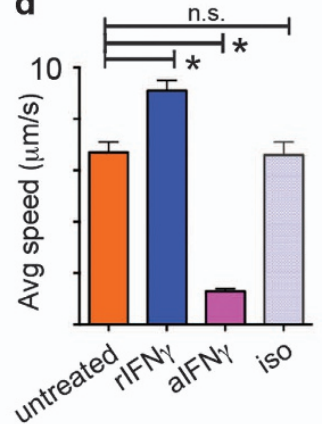

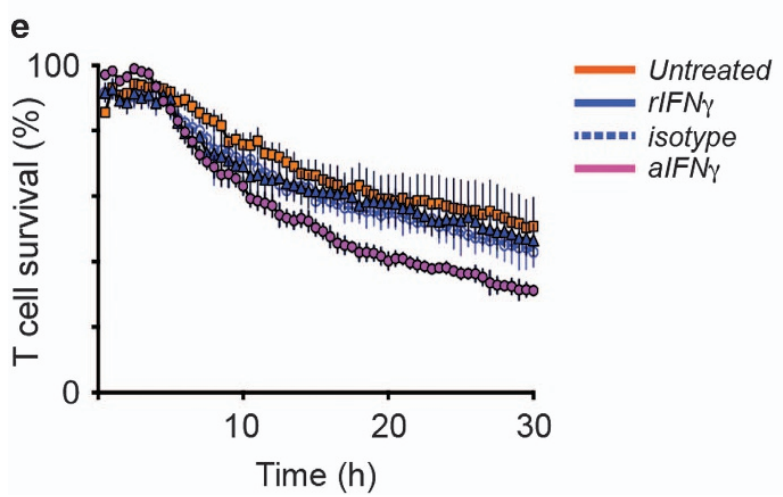

Figure 6 Suppression of autocrine signaling of IFNy on CTL inhibits their cytotoxicity and motility. IFNy ${ }^{-1}$ CTL cells or EGFP+OT-I CTL pre-treated with PBS, rlFNy or antiIFNy for $4 \mathrm{~h}$, were co-cultured with SIINFEKL-loaded target KC. The kinematics of CTL were analyzed using fluorescence time-lapse movies of $30 \mathrm{~h}$ as above. (a) Examples of images of tracked CD8 T cells. Displacement is shown in white arrows, and track length and mean speed are shown in color. Scale bars, $50 \mu \mathrm{m}$. (b-d) Pre-treated B6 CTL or IFNy ${ }^{-1-}$ CTL in co-culture with targets for $30 \mathrm{~h}$ were investigated for vectorial displacement, distance traveled, and mean speed. Data are pooled results of 3 independent experiments (around 200 cells). Error bars are SEM. $\left({ }^{*} P<0.05\right.$, n.s. not significant) (e) Rate of death of pre-treated CD8 $\mathrm{T}$ cells during co-culture with target cells. The number of surviving $\mathrm{T}$ cells was determined by software, expressing the number of green cells (size $>7 \mu \mathrm{m}$ ) at each frame as a percentage of the number of cells at the start. $N=3$. Error bars are s.e.m.

motility kinetics and cytolytic activity of CD8 T cells post IFN $Y$ treatment likely reflects intracellular metabolic changes induced by the cytokine. Prolonged IFNY-deprivation, achieved by a depleting antibody, resulted in irreversible changes to CD8 T-cell function, suggesting that CD8 T cells heavily rely on autocrine IFN $\gamma$ to maintain cytolytic and kinetic function. Granzyme B and IFN $\gamma$ expression was impaired in the absence of IRF3 in murine models..$^{45}$ Activation of the TCR together with its co-receptor has been shown to result in activation of STAT proteins within the cell one hour later, 
a

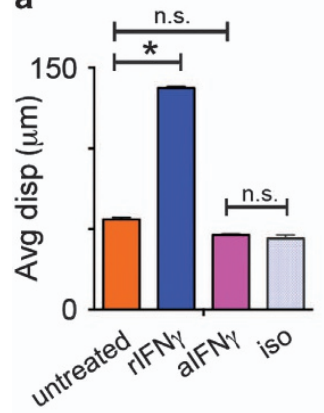

b

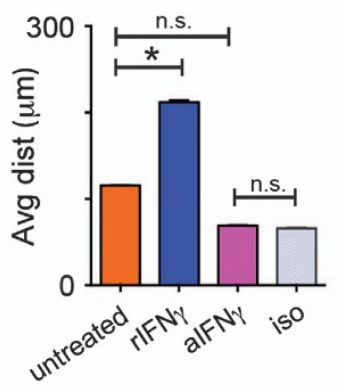

C

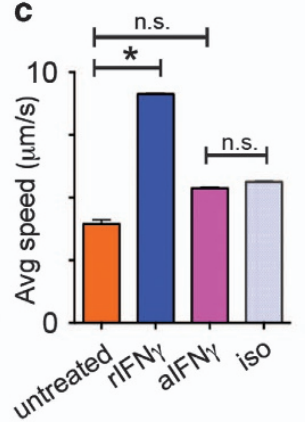

d

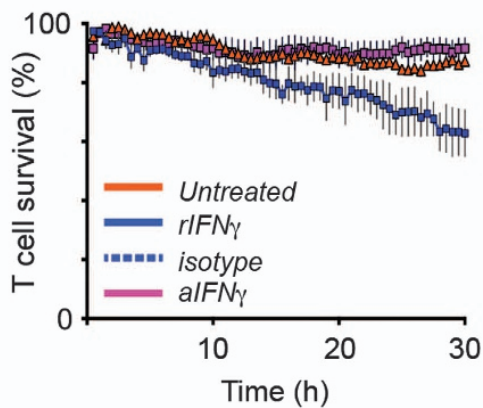

Figure 7 IFN $\gamma$-deficient cells show reduced kinematics but respond to IFN $\gamma$. CTL from OVA-immunized IFN $\gamma$-/- mice were pre-treated with rIFN $\gamma$ or alFN $\gamma$ or isotype control antibody for four hours prior to co-culture with KC presenting SIINFEKL peptide. Cultures were imaged for $30 \mathrm{~h}$ as above. (a-c) Movies were analyzed for CTL displacement, track length, and average track speed. (d) CTL survival was calculated by comparing the number of CTL in the final imaging frames with those in the initial frames. $\left({ }^{*} P<0.05\right.$, n.S., not significant)

suggesting that any metabolic effects of IFN $\gamma$ are likely to be slow rather than immediate, ${ }^{46}$ in keeping with our data where cells were treated for $4 \mathrm{~h}$ with inhibitor.

We describe a process of CD8 T-cell-mediated antigenspecific killing of keratinocytes that is reliant on IFN $\gamma$ at multiple interfaces. The cell-specific resistance to CTL exhibited by keratinocytes is related to their susceptibility to IFN $\gamma$, and mediated by the IFN $\gamma$ R. We also show that CD8 T cells are themselves up regulated by IFN $\gamma$, and that these effector cells are reliant on their ability to produce IFN $\gamma$ for their own function and survival. Further studies in vivo examining these mechanisms utilizing systemic blockade of IFN $\gamma$ and local and systemic supply of the cytokine will be of value. The reliance of the CTL-mediated killing of keratinocytes on IFN $\gamma$ at multiple levels emphasizes its importance as a mediator of effector T-cell function.

\section{Materials and Methods}

Mice. Experiments were approved by the University of Queensland animal ethics committee. B6.K5mOva (K5mOva) mice were a kind gift from Dr W.R. Heath, WEHI, Parkville, Australia. B6.OT-I and B6.RAG-1 ${ }^{-1-}$ mice were purchased from the Animal Resource Centre, Perth, Australia. B6.IFN $\gamma^{-1-}$ and $\mathrm{B} 6 . \mathrm{IFN} \gamma \mathrm{R}^{-1-}$ mice were purchased from Jackson Laboratories, Bar Harbor, ME, USA. B6.Nzeg (EGFP'B6) mice were bred with OT-I mice to create OT-1.Nzeg (EGFP+OT-I) mice, and with $\mathrm{B} 6 . \mathrm{IFN} \gamma^{-1-}$ to create $\mathrm{IFN} \gamma^{-1-}$.Nzeg $\left(\mathrm{EGFP}^{+} \mathrm{IFN} \gamma^{-1-}\right)$ mice. We confirmed the EGFP expression did not act as an alloantigen by the acceptance of skin grafts from these mice onto C57/B6 (B6) mice, and by co-culture of EGFP ${ }^{+}$ lymphocytes with B6 lymphocytes which did not result in increased cell death.

Reagents. The following antibodies were purchased from $B D$ Pharmingen (San Jose, CA, USA): anti-CD44 APC-Cy7, anti-IFN $\gamma$ PE-Cy7, CD8 PE, and CD8 APC, relevant isotype antibodies. Anti-CD62L PE and anti-IFN $\gamma$ capture antibody (Clone R4-6A2) were purchased from eBioscience (San Diego, CA, USA). Anti-GFP FITC was purchased from Abcam (Cambridge, UK). SR-FLIVO-red was courtesy of ImmunoChemistry laboratories (Bloomington, MN, USA). All cell culture media was purchased from Invitrogen (Carlsbad, CA, USA). Recombinant IFN $\gamma$ was purchased from R\&D Systems (Minneapolis, MN, USA). Z-DVED-FMK, Ovalbumin (OVA) and SIINFEKL peptide were purchased from Sigma-Aldrich (St. Louis, MO, USA).

Mouse experiments. For grafting, mice were used between 6 and 8 weeks of age. Adoptive transfer of cells was performed by tail vein injection of $10^{6}$ cells concentrated into $100 \mu \mathrm{l}$ of saline. Administration of antibody was performed by intraperitoneal injection of $200 \mu \mathrm{g}$ anti-IFN $\gamma$ or isotype control antibody, diluted into $200 \mu \mathrm{l}$ saline administered at the time of adoptive transfer and weekly thereafter.

Skin grafting. Grafting of murine ear skin to flank was performed as previously described. ${ }^{47}$ Briefly, donor ears were split antero-posterior and the cartilage scraped. A comparable size of skin was excised from the recipient mouse and the graft was placed dermis-side down over the deficit. The graft was bandaged in place for 7 days. Grafts were deemed rejected if there was $>80 \%$ loss of epithelium, and as accepted if there was no rejection by day 50 .

Activation of CD8 T cells. Mice were immunized with OVA $(50 \mu \mathrm{g})$ and QuilA $(20 \mu \mathrm{g})$, or mock-immunized, subcutaneously at the base of the tail. 10 days later, isolated CD8 T cells from immunized mice were cultured for 3 days in complete RPMI, with IL-2 $10 \mathrm{ng} / \mathrm{ml}$, and SIINFEKL peptide $1 \mu \mathrm{g} / \mathrm{ml}$. Activation of cells was confirmed by flow cytometry for $\operatorname{CD} 8^{+} C D 44^{\text {high }} \mathrm{T}$ cells. In adoptive transfer experiments, $10^{6} \mathrm{CD}^{+} \mathrm{CD} 44^{\text {high }} \mathrm{T}$ cells were injected by tail vein.

Keratinocyte harvest and culture. Primary KC were harvested from neonatal mice aged 3-4 days as described previously. ${ }^{48}$ Briefly, skins were removed from sacrificed mouse pups and digested overnight at $4{ }^{\circ} \mathrm{C}$ in $10 \%$ dispase solution containing $1 \%$ penicillin, streptomycin and gentamycin, before brief trypsinisation and resuspension of separated primary KC in DMEM. KC were seeded at $30-50 \%$ confluence in DMEM with $5 \%$ FCS for $24 \mathrm{~h}$, onto 24 - or 47 -well tissue culture plates. Media was changed to keratinocyte serum-free medium supplemented with bovine pituitary extract and epidermal growth factor $24 \mathrm{~h}$ later. Cells were used for imaging at $60-70 \%$ confluence.

Co-culture experiments. SIINFEKL peptide $1 \mu \mathrm{g} / \mathrm{ml}$ was added to the $\mathrm{KC}$ medium for $1 \mathrm{~h}$ at $37^{\circ} \mathrm{C}$, and cells then washed 3 times in PBS to remove nonincorporated peptide. CD8 T cells $5 \times 10^{3}$ were added per well in duplicate wells. Cells were imaged at $37^{\circ} \mathrm{C}$ with $5 \% \mathrm{CO}_{2}$ for $30 \mathrm{~h}$ in imaging media, comprising $45 \%$ RPMI, $5 \%$ FCS, $50 \%$ serum-free medium, $5 \mathrm{ng} / \mathrm{ml} \mathrm{IL-2}$ and $2 \%$ FLIVO-SR red solution. Each plate included control wells of co-cultures without peptide and $\mathrm{KC}$ monocultures. Where indicated, recombinant IFN $\gamma(1 \mu \mathrm{g} / \mathrm{ml})$, anti-IFN $\gamma(1 \mu \mathrm{g} / \mathrm{ml})$, or isotype control antibody were added to the media.

Flow cytometry. Single-cell suspensions of leukocytes were prepared with complete RPMI inclusive of $5 \%$ FCS, $1 \%$ penicillin and streptomycin. Pelleted cells were lysed with ACK lysis buffer (Invitrogen), and washed in sterile FACS-buffer comprising PBS with 5\% FCS. For T-cell selection, resuspended cells were stained with anti-CD8 APC antibody, and $1 \mu \mathrm{g}$ propidium iodide (Invitrogen). FACS was used to obtain a $>98 \%$ pure population of $\mathrm{APC}^{+}, \mathrm{Pl}^{-}$cells (Moflo, Beckman Coulter, Brea, CA, USA). Cells were washed in sterile PBS in preparation for transfer to recipient mice by tail vein injection, or resuspended in complete RPMl for culture. For flow cytometric examination, surface staining of single-cell suspensions were performed at $4{ }^{\circ} \mathrm{C}$ before fixation in $1 \%$ formalin in PBS. Where intracellular cytokine staining was required, T cells were pre-stimulated with $25 \mathrm{ng} / \mathrm{ml}$ PMA/ ionomycin (Sigma-Aldrich) in the presence of $1 \mu \mathrm{g}$ monensin (Sigma-Aldrich) for $4 \mathrm{~h}$ at $37^{\circ} \mathrm{C}$. Cells were then put on ice and surface stained, before incubation in fixation and permeabilisation buffer (BD Systems, Franklin Lakes, NJ, USA) for $30 \mathrm{~min}$ before intracellular staining. Flow cytometry was performed using FacsCanto (BD Systems).

Immunofluorescence. Grafted mice were injected intravenously with FLIVO$\mathrm{SR}$ red prior to sacrifice. Frozen sections of excised skin grafts of mice receptive of 
adoptively transferred CD8 $\mathrm{T}$ cells were stained with GFP-conjugated anti-CD8 antibody $2 \mathrm{~h}$ at $4{ }^{\circ} \mathrm{C}$ before fixation in $4 \%$ paraformaldehyde (ProSciTech), mounting and examination. In experiments where intravenous FLIVO-SR red was not used, these slides were stained with Alexa 555-conjugated anti-CD8 antibody and FITC-conjugated anti-GFP antibody, before fixation and mounting.

Microscopy. Confocal microscopy of slides was performed on a Zeiss (Oberkochen, Germany) Meta-250 confocal microscope with $\times 25$ oil objective lens, taking $2 \mu \mathrm{m}$ Z-sections. Extended-duration time-lapse microscopy was performed on a Zeiss Axiovert 200M microscope acquiring images using a Zeiss AxioCamMR camera. Images binned $4 \times 4$ were acquired from duplicate wells using a $\times 10$ objective lens. Cells were maintained with humidification, in $5 \% \mathrm{CO}_{2}$, at $37^{\circ}$ $\mathrm{C}$ during imaging. Images were taken every $12 \mathrm{~min}$ for $30 \mathrm{~h}$. We have previously optimized the imaging frequency of these co-cultures to obtain maximal duration of imaging with no detectable phototoxicity. ${ }^{28}$ While the track length and mean track speed depend on imaging frequency, as the same time gaps between images were used for all cultures, including controls, and as each imaged culture plate comprised all controls and experimental samples, the variation is assumed to be similar in both treated and control wells. Indeed in earlier studies we confirmed that imaging with increasing frequency made little difference to mean track length or speed over $4 \mathrm{~h}$ of imaging, but markedly increased culture cell death due to phototoxicity seen as cell membrane damage and porosity. ${ }^{28}$

Multiphoton microscopy. Mice anaesthetized with inhaled isoflurane, were warmed on a heating pad regulated by core rectal temperature measurements. A longitudinal incision was made either side of the graft and a glass slide was used to elevate the flank skin. A coverslip in a heated chamber was placed over the graft. A LaVision multiphoton microscopy system with Mai Tai laser with a $\times 16$ dipping objective lens was used to acquire images. Images were acquired every $60 \mathrm{~s}$ for 15-30 min. Where a graft was still in place, imaging was performed at the edge of the graft; where a graft was rejected, the site of graft placement was imaged.

Image analysis. Imaris 7.4.2 software (Bitplane, Ulster, UK) was used to deconvolute and analyze images, and generate movies. Numerical data were analyzed using raw images. Analysis parameters were optimized for each image, to minimize mis-tracking. T cells were identified using the spot selection and tracking software by size $(7 \mu \mathrm{m})$ and EGFP expression, and tracked through each frame. We excluded tracks within $10 \mu \mathrm{m}$ from the edge, and tracked with maximum gap size 1 , and distance $20-50 \mu \mathrm{m}$. Spots and tracks were manually corrected in up to $10 \%$ of cells per field. Cell death was determined by fluorescence in the red channel and size: KC $20 \mu \mathrm{m}, \mathrm{CTL} 7 \mu \mathrm{m}$. Data were exported into Excel and into Graphpad Prism for statistical analysis. Spectral separation was where required, and a $3 \times 3$ median filter and minor contrast adjustments were performed using Imaris or Adobe Photoshop on still images and movies for publication. Further details regarding parameters used for analysis, spot selection, Imaris algorithms and validation of the techniques have been previously described in detail. ${ }^{28}$

Statistics. Intravital imaging data were collected from multiple sites per animal and averaged. Cell culture data were collected from duplicate wells and averaged. $N$ refers to the number of independent experiments performed. We used the onetailed Mann-Whitney test to compare non-parametric data, the KolmogorovSmirnov comparative test (K-S test) to compare two frequency distributions that were non-normal and the Mantel-Cox test was applied to survival data as indicated in the text. Data were considered significantly different if $P<0.05$.

\section{Conflict of Interest}

The authors declare no conflict of interest.

Acknowledgements. IHF was supported by grants from National Health and Medical Research Council of Australia Program Grant-569938, National Cancer Institute (NIH)-U01-015317, Australian Cancer Research Foundation. IHF and PB were supported by a Cancer Council Queensland research grant.

1. Martinet L, Garrido I, Filleron T, Le Guellec S, Bellard E, Fournie JJ et al. Human solid tumors contain high endothelial venules: association with $\mathrm{T}$ - and B-lymphocyte infiltration and favorable prognosis in breast cancer. Cancer Res 2011; 71: 5678-5687.
2. Peng LS, Zhuang $\mathrm{Y}$, Shi $\mathrm{Y}$, Zhao $\mathrm{YL}$, Wang $\mathrm{TT}$, Chen $\mathrm{N}$ et al. Increased tumor-infiltrating CD8(+)Foxp3 (+) T lymphocytes are associated with tumor progression in human gastric cancer. Cancer Immunol Immunother 2012; 61: 2183-2192.

3. Bellavance EC, Kohlhapp FJ, Zloza A, O'Sullivan JA, McCracken J, Jagoda MC et al. Development of tumor-infiltrating CD8+ T cell memory precursor effector cells and antimelanoma memory responses are the result of vaccination and TGF- $\beta$ blockade during the perioperative period of tumor resection. J Immunol 2011; 186: 3309-3316.

4. Sikora AG, Jaffarzad N, Hailemichael Y, Gelbard A, Stonier SW, Schluns KS et al. IFN- $\alpha$ enhances peptide vaccine-induced CD8+ T cell numbers, effector function, and antitumor activity. J Immunol 2009; 182: 7398-7407.

5. Ruocco MG, Pilones KA, Kawashima N, Cammer M, Huang J, Babb JS et al. Suppressing T cell motility induced by anti-CTLA-4 monotherapy improves antitumor effects. J Clin Invest 2012; 122: 3718-3730.

6. Ahmadzadeh M, Johnson LA, Heemskerk B, Wunderlich JR, Dudley ME, White DE et al. Tumor antigen-specific CD8 T cells infiltrating the tumor express high levels of PD-1 and are functionally impaired. Blood 2009; 114: 1537-1544.

7. Kilinc MO, Aulakh KS, Nair RE, Jones SA, Alard P, Kosiewicz MM et al. Reversing tumor immune suppression with intratumoral IL-12: activation of tumor-associated T effector/ memory cells, induction of $\mathrm{T}$ suppressor apoptosis, and infiltration of CD8+ T effectors. $\mathrm{J}$ Immunol 2006; 177: 6962-6973.

8. Keppler SJ, Theil K, Vucikuja S, Aichele P. Effector T-cell differentiation during viral and bacterial infections: Role of direct IL-12 signals for cell fate decision of CD8(+) T cells. Eur J Immunol 2009; 39: 1774-1783.

9. Welters MJ, Kenter GG, Piersma SJ, Vloon AP, Lowik MJ, Berends-van der Meer DM et al. Induction of tumor-specific CD4+ and CD8+ T-cell immunity in cervical cancer patients by a human papillomavirus type 16 E6 and E7 long peptides vaccine. Clin Cancer Res 2008; 14: 178-187.

10. Villegas-Mendez A, de Souza JB, Murungi L, Hafalla JC, Shaw TN, Greig R et al. Heterogeneous and tissue-specific regulation of effector T cell responses by IFN- $\gamma$ during Plasmodium berghei ANKA infection. J Immunol 2011; 187: 2885-2897.

11. Arany I, Tyring SK, Brysk H, Brysk MM. Induction by interferon-gamma of its receptor varies with epithelial differentiation and cell type. Arch Dermatol Res 1998; 290: 331-334.

12. Saunders NA, Jetten AM. Control of growth regulatory and differentiation-specific genes in human epidermal keratinocytes by interferon gamma. Antagonism by retinoic acid and transforming growth factor beta 1. J Biol Chem 1994; 269: 2016-2022.

13. Karlsson $T$, Vahlquist $A$, Torma $H$. Keratinocyte differentiation induced by calcium, phorbol ester or interferon-gamma elicits distinct changes in the retinoid signalling pathways. J Dermatol Sci 2010; 57: 207-213.

14. Nandi B, Behar SM. Regulation of neutrophils by interferon-gamma limits lung inflammation during tuberculosis infection. J Exp Med 2011; 208: 2251-2262.

15. Sarkar S, Cooney LA, White P, Dunlop DB, Endres J, Jorns JM et al. Regulation of pathogenic IL-17 responses in collagen-induced arthritis: roles of endogenous interferongamma and IL-4. Arthritis Res Ther 2009; 11: R158.

16. Pelletier M, Maggi L, Micheletti A, Lazzeri E, Tamassia N, Costantini C et al. Evidence for a cross-talk between human neutrophils and Th17 cells. Blood 2010; 115: 335-343.

17. Ligocki AJ, Brown JR, Niederkorn JY. Role of interferon-gamma and cytotoxic T lymphocytes in intraocular tumor rejection. J Leukoc Biol 2016; 99: 735-747.

18. Zhou J, Ma P, Li J, Cui X, Song W. Improvement of the cytotoxic T lymphocyte response against hepatocellular carcinoma by transduction of cancer cells with an adeno-associated virus carrying the interferon-gamma gene. Mol Med Rep 2016; 13: 3197-3205.

19. Gollob JA, Kawasaki H, Ritz J. Interferon-gamma and interleukin-4 regulate T cell interleukin12 responsiveness through the differential modulation of high-affinity interleukin-12 receptor expression. Eur J Immunol 1997; 27: 647-652.

20. Badovinac VP, Tvinnereim AR, Harty JT. Regulation of antigen-specific CD8+ T cell homeostasis by perforin and interferon-gamma. Science 2000; 290: 1354-1358.

21. Remakus S, Sigal LJ. Gamma interferon and perforin control the strength, but not the hierarchy, of immunodominance of an antiviral CD8+ T cell response. J Virol 2011; 85: 12578-12584.

22. McKenzie MD, Dudek NL, Mariana L, Chong MM, Trapani JA, Kay TW et al. Perforin and Fas induced by IFNgamma and TNFalpha mediate beta cell death by OT-I CTL. Int Immunol 2006; 18: 837-846.

23. Cone RE, Li X, Sharafieh R, O'Rourke J, Vella AT. The suppression of delayed-type hypersensitivity by CD8+ regulatory T cells requires interferon-gamma. Immunology 2007; 120: $112-119$.

24. Issekutz TB, Stoltz JM, van der Meide P. The recruitment of lymphocytes into the skin by T cell lymphokines: the role of gamma-interferon. Clin Exp Immunol 1988; 73: 70-75.

25. Kaplan G, Luster AD, Hancock G, Cohn ZA. The expression of a gamma interferon-induced protein (IP-10) in delayed immune responses in human skin. $J$ Exp Med 1987; 166: 1098-1108.

26. De Kluyver RL, Moritz L, Harris CA, Azukizawa H, Frazer IH. Antigen-specific CD8 T cells can eliminate antigen-bearing keratinocytes with clonogenic potential via an IFN-gammadependent mechanism. J Invest Dermatol 2010; 130: 1841-1848.

27. Mattarollo SR, Yong M, Tan L, Frazer IH, Leggatt GR. Secretion of IFN-gamma but not IL-17 by CD1d-restricted NKT cells enhances rejection of skin grafts expressing epithelial cell-derived antigen. J Immunol 2010; 184: 5663-5669.

28. Bhat $P$, Leggatt $G$, Matthaei KI, Frazer IH. The kinematics of cytotoxic lymphocytes influence their ability to kill target cells. PLOS ONE 2014; 9: e95248. 
29. Celli S, Albert ML, Bousso P. Visualizing the innate and adaptive immune responses underlying allograft rejection by two-photon microscopy. Nat Med 2011; 17: 744-749.

30. Halle S, Keyser KA, Stahl FR, Busche A, Marquardt A, Zheng X et al. In vivo killing capacity of cytotoxic $T$ cells is limited and involves dynamic interactions and $T$ cell cooperativity. Immunity 2016; 44: 233-245.

31. Bocek P Jr, Foucras G, Paul WE. Interferon gamma enhances both in vitro and in vivo priming of CD4+ T cells for IL-4 production. J Exp Med 2004; 199: 1619-1630.

32. Dalton DK, Pitts-Meek S, Keshav S, Figari IS, Bradley A, Stewart TA. Multiple defects of immune cell function in mice with disrupted interferon-gamma genes. Science 1993; 259: $1739-1742$.

33. Tvinnereim AR, Harty JT. CD8(+) T-cell priming against a nonsecreted Listeria monocytogenes antigen is independent of the antimicrobial activities of gamma interferon. Infect Immunity 2000; 68: 2196-2204.

34. Tau GZ, Cowan SN, Weisburg J, Braunstein NS, Rothman PB. Regulation of IFN- $\gamma$ signaling is essential for the cytotoxic activity of CD8(+) T cells. J Immunol 2001; 167: 5574-5582.

35. Whitmire JK, Tan JT, Whitton JL. Interferon-gamma acts directly on CD8+ T cells to increase their abundance during virus infection. J Exp Med 2005; 201: 1053-1059.

36. Jiang X, Clark RA, Liu L, Wagers AJ, Fuhlbrigge RC, Kupper TS. Skin infection generates non-migratory memory CD8+ T(RM) cells providing global skin immunity. Nature 2012; 483 : 227-231.

37. Broom JK, Lew AM, Azukizawa H, Kenna TJ, Leggatt GR, Frazer IH. Antigen-specific CD4 cells assist CD8 T-effector cells in eliminating keratinocytes. J Invest Dermatol 2010; 130: $1581-1589$.

38. Lambert Emo K, Hyun YM, Reilly E, Barilla C, Gerber S, Fowell D et al. Live Imaging of Influenza Infection of the Trachea Reveals Dynamic Regulation of CD8+ T Cell Motility by Antigen. PLOS Pathog 2016; 12: e1005881.

39. Sanderson NS, Puntel M, Kroeger KM, Bondale NS, Swerdlow M, Iranmanesh N et al. Cytotoxic immunological synapses do not restrict the action of interferon-gamma to antigenic target cells. Proc Natl Acad Sci USA 2012; 109: 7835-7840.

40. Taniguchi K, Yamamoto S, Hitomi E, Inada Y, Suyama Y, Sugioka T et al. Interleukin 33 is induced by tumor necrosis factor alpha and interferon gamma in keratinocytes and contributes to allergic contact dermatitis. J Invest Allergol Clin Immunol 2013; 23: 428-434.

41. Ben-Sasson SZ, Hogg A, Hu-Li J, Wingfield P, Chen X, Crank M et al. IL-1 enhances expansion, effector function, tissue localization, and memory response of antigen-specific CD8 T cells. J Exp Med 2013; 210: 491-502.
42. Rodig N, Ryan T, Allen JA, Pang H, Grabie N, Chernova T et al. Endothelial expression of PD-L1 and PD-L2 down-regulates CD8+ T cell activation and cytolysis. Eur J Immunol 2003 33: 3117-3126.

43. Wang X, Berger C, Wong CW, Forman SJ, Riddell SR, Jensen MC. Engraftment of human central memory-derived effector CD8+ T cells in immunodeficient mice. Blood 2011; 117: 1888-1898.

44. Refaeli Y, Van Parijs L, Alexander SI, Abbas AK. Interferon gamma is required for activationinduced death of T lymphocytes. J Exp Med 2002; 196: 999-1005.

45. Guinn Z, Lampe AT, Brown DM, Petro TM. Significant role for IRF3 in both T cell and APC effector functions during T cell responses. Cell Immunol 2016; 310: 141-149.

46. Chueh FY, Yu CL. Engagement of T-cell antigen receptor and CD4/CD8 co-receptors induces prolonged STAT activation through autocrine/paracrine stimulation in human primary T cells. Biochem Biophys Res Commun 2012; 426: 242-246.

47. Frazer IH, Fernando GJ, Fowler N, Leggatt GR, Lambert PF, Liem A et al. Split tolerance to a viral antigen expressed in thymic epithelium and keratinocytes. Eur J Immunol 1998; 28: 2791-2800.

48. Leggatt GR, Dunn LA, De Kluyver RL, Stewart T, Frazer IH. Interferon-gamma enhances cytotoxic $T$ lymphocyte recognition of endogenous peptide in keratinocytes without lowering the requirement for surface peptide. Immunol Cell Biol 2002; 80: 415-424.

Cell Death and Disease is an open-access journal published by Nature Publishing Group. This work is licensed under a Creative Commons Attribution 4.0 International License. The images or other third party material in this article are included in the article's Creative Commons license, unless indicated otherwise in the credit line; if the material is not included under the Creative Commons license, users will need to obtain permission from the license holder to reproduce the material. To view a copy of this license, visit http://creativecommons.org/licenses/by/4.0/

(C) The Author(s) 2017

Supplementary Information accompanies this paper on Cell Death and Disease website (http://www.nature.com/cddis) 